\title{
Choroid plexus papilloma in a Rottweiler: computed tomographic, gross morfological and histological features
}

[Papiloma do plexo coroide em um cão da raça Rottweiler: aspectos tomográficos, macroscópicos e histológicos]

A.C.B.C. Fonseca Pinto, L.A. Villamizar ${ }^{*}$, C.O. Ghirelli, T.R.C. Silva, C.O. Baroni, G.P.R. Banon, J.M. Guerra, C.T. Amaral, L.N. Torres

Universidade de São Paulo - São Paulo, SP

\begin{abstract}
Among the tumors affecting the choroid plexus in dogs, the papilloma ranks second place in incidence after cell carcinoma tumors. Presumptive diagnosis can be made through imaging methods, such as computed tomography and magnetic resonance images. Definitive diagnosis of plexus choroid tumor is based on histopathological findings. This report presented the tomographic features of the brain in a 6year-old intact female Rottweiler with choroid plexus papilloma. The computed tomography showed right lateral ventricle enlargement, midline deviation and an enhanced mass into the postcontrast phase. At necropsy, a mass on the floor of the right lateral ventricle was observed, associated with important ventricle dilatation. The histopathological analysis demonstrated the presence of neoplastic cell forms with papillary projections. The computed tomography proved to be an effective tool in the presumptive diagnosis of this kind of cerebral disorder.
\end{abstract}

Keywords: dog, computed tomography, choroid plexus, tumor

\section{RESUMO}

Dentre os tumores que afetam o plexo coroide em cães, o papiloma figura como o segundo tipo de maior incidência, antecedido apenas pelo carcinoma. O diagnóstico presuntivo pode ser elaborado por meio de métodos de imagem, como a tomografia computadorizada e a ressonância magnética. O diagnóstico definitivo de tumor do plexo coroide é estabelecido com base nos achados histopatológicos. Relatamos os aspectos tomográficos do crânio em uma fêmea de 6 anos, inteira, da raça Rottweiler, com papiloma do plexo coroide. A tomografia computadorizada revelou dilatação do ventrículo lateral direito, desvio da linha média e a presença de uma massa, que sofreu realce na fase pós-contraste. À necropsia, foi observada uma massa sobre o assoalho do ventrículo lateral direito, associada à importante dilatação ventricular. A análise histopatológica demonstrou a presença de células poligonais neoplásicas, arranjadas em papilas longas. A tomografia computadorizada apresentou-se como uma ferramenta eficaz no diagnóstico presuntivo desse tipo de alteração cerebral.

Palavras-chave: cão, tomografia computadorizada, plexo coroide, tumor

\section{INTRODUCTION}

The choroid plexus epithelium originates from the differentiation of the primitive medullary epithelium and it is embryologically related to ependymal cells (Hammer et al., 1990). The floor of each lateral ventricle and the roof of the third and fourth ventricles of the brain are partly covered by an epithelium called "tela choroidea", in which blood microvessels originate, covering the ependymal epithelium. This vascular structure is projected into the ventricular cavities in the form of villi, thus giving rise to the choroid plexus (CP). The

Recebido em 11 de outubro de 2011

Aceito em 8 de outubro de 2012

*Autor para correspondência (corresponding author)

E-mail: leninvet@usp.br 
function of the $\mathrm{CP}$ is forming and maintaining the cerebrospinal fluid (CSF) by secretion and filtration (Fletcher, 1993).

Intraventricular brain tumors make up approximately $9 \%$ of tumors affecting the entire central nervous system (Koestner and Higgins, 2002). Choroid plexus carcinoma (CPC) is the most common $\mathrm{CP}$ tumor, followed by the choroid plexus papilloma, affecting dogs with a average age of 5 and 7 years respectively (Nashold et al., 1961; Westworth et al., 2008).

The choroid plexus papilloma (CPP) has no predilection for females or males, or brachycephalic or mesaticephalic dogs. CPP has been found frequently in the fourth ventricle, however, it may also appear affecting the third and lateral ventricles (Kurtz and Hanlon, 1971). Ventriculomegaly and hidrocephaly are conditions related to ventricular tumors due to CSF flow obtruction and drainage failure (Nashold et al., 1961; Westworth et al., 2008).

Presumptive diagnosis may be made through CSF analysis and imaging methods such as computed tomography (CT) and magnetic resonance image (MRI). In an earlier study of dogs with choroid plexus tumors (CPT), CPC and CPP, conducted by Westworth et al. (2008), the CSF analysis of dogs affected by CPC evidenced an increased protein concentration, with a median of $108 \mathrm{mg} / \mathrm{dL}$ (reference range: $<25 \mathrm{mg} / \mathrm{dL}$ ) significantly higher than the values of the animals with CCP, which had a median of $34 \mathrm{mg} / \mathrm{dL}$. The study also showed an increase of a total nucleated cell count median: 13 cells $/ \mu \mathrm{L}$ (reference range $<5$ cells $/ \mu \mathrm{L}$ ). The imaging methods (CT and MRI) suggest CPT based on the presence of intraventricular mass (Hammer et al., 1990; Westworth et al., 2008). A definitive diagnosis of CPT is based on histopathological findings (Koestner and Higgins, 2002; Westworth et al., 2008).

\section{CASE REPORT}

A 6-year-old intact female Rottweiler was assessed for 1 month progressive symptoms consisting in fainting, dyspnea, generalized tremors, apparent blindness, right propulsive circling, head pressing, excessive vocalization and changes in behavior. A neurologic examination revealed depression, thoracic and pelvic limb ataxia, hypotonic muscle tone and absence of blink response to threat. Serum biochemical analysis revealed an increase of the alkaline phosphatase (216U/L; reference range 20-150U/L). No abnormalities were detected on hematologic and electrolytic analysis. Head computed tomography was performed.

Computed tomography (CT) was performed using a single slice helical scanner. The patient was positioned in sternal recumbence with the thoracic limbs out of the gantry. Transverse slices of the head with $5 \mathrm{~mm}$ thickness, $5 \mathrm{~mm}$ of increment, $150 \mathrm{~mA}$ and $120 \mathrm{kVp}$ were made. The images were obtained pre and post intravenous bolus injection of ionic iodine contrast (Urografina $^{\circledR}$ 292, Berlimed SA Alcalá de Henares - Madri - Espanha, Laboratórios Schering do Brasil), with a volume of $1.5 \mathrm{ml} / \mathrm{kg}$. Multiplanar image reconstructions were also obteined. CT images were analyzed with bone and soft tissue window selection and they showed asymmetric dilatation of the lateral ventricles with severe enlargement of the right lateral ventricle and presence of an isoattenuating (in relation to the brain parenchyma) mass located on the floor of the enlarged right lateral ventricle, which underwent intense enhancement after the intravenous contrast administration. An accented midline shift toward the opposite site was also observed (Fig. 1).

The patient was euthanized after 20 days of admission due to the worsening of symptoms and poor response to the treatment. At necropsy, a no encapsulated, grayish granular mass was observed within the right lateral ventricle, measuring $1.2 \times 0.5 \mathrm{~cm}$ (Fig. 2). Upon histopathological examination, the ventral parts of the lateral ventricles were infiltrated by a multinodular, demarcated, partially encapsulated mass with a moderate cellularity. The tumor was composed of well-differentiated, papillary structures lined by a single layer of non-ciliated epithelium, supported by a delicate fibrovascular stroma. The neoplastic cells were cuboidal or columnar, with well-defined cytoplasmic borders. The cytoplasm was abundant and pale eosinophilic. The nucleus was round, basally located, euchromatic with coarse chromatin. The mitotic index was low. No signs of cellular atypia. No embolus was found (Fig. 3). 

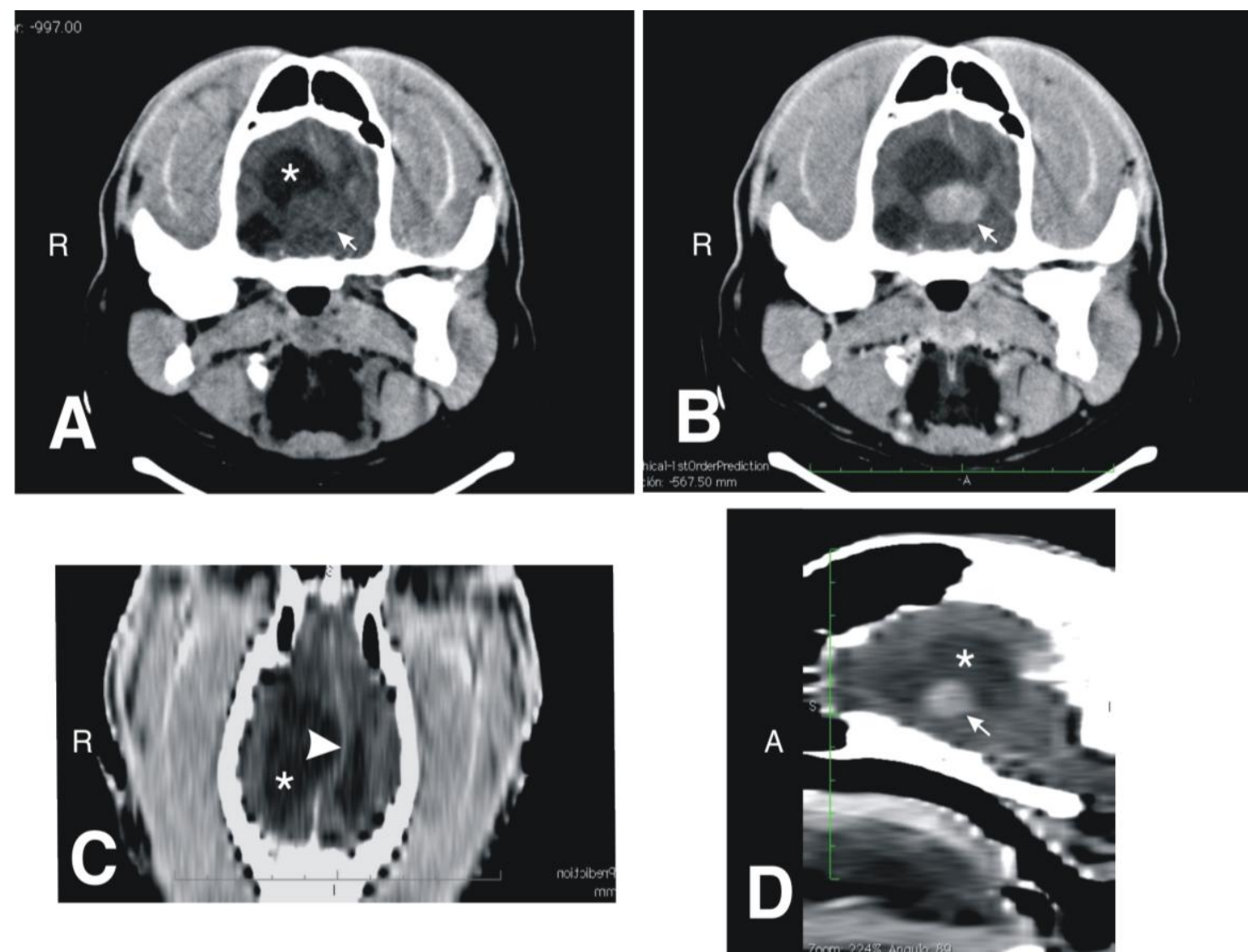

Figure 1. Dog. Precontrast (A) and postcontrast (B-C-D) computed tomography images of the reported dog. (A) Right lateral ventricle dilation (*) associated with a presence of a soft tissue mass (arrow) on the lateral right ventricle floor. (B) Strong enhancement of the in the right lateral ventricle. Dorsal (C) and sagittal (D) reconstructed images showing severe right lateral ventricle enlargement $(*)$, midline deviation to the left (arrowhead), and enhanced mass (arrow).

\section{DISCUSSION}

A case of a 6-year-old female Rottweiler with a choroid plexus papilloma affecting the right lateral ventricle was presented. According to the literature, CPT do not only affect the fourth ventricle, they may also appear in other areas of the ventricular system. The age of the dog in this case was within the 3-13 age range reported by other authors (Kurtz and Hanlon, 1971; Westworth et al., 2008).

MRI enables the acquisition of multiplanar highresolution images, offering additional advantage in the visualization of the lesion. However, the computed tomography proved to be an effective tool on the presumptive diagnosis of choroid plexus tumor in the dog in this report. The CT images allowed the observation of the hydrocephalus degree and tumor location, determining if the tumor was confined to the ventricular cavity or infiltrating the brain parenchyma. After intravenous contrast bolus injection, an intense mass enhancement was observed, which was associated to the vascular origin of the choroid plexus as related by Fletcher (1993) and Melo et al. (2003). The main advantages of CT over MRI are that the CT is faster, less expensive and more available. 

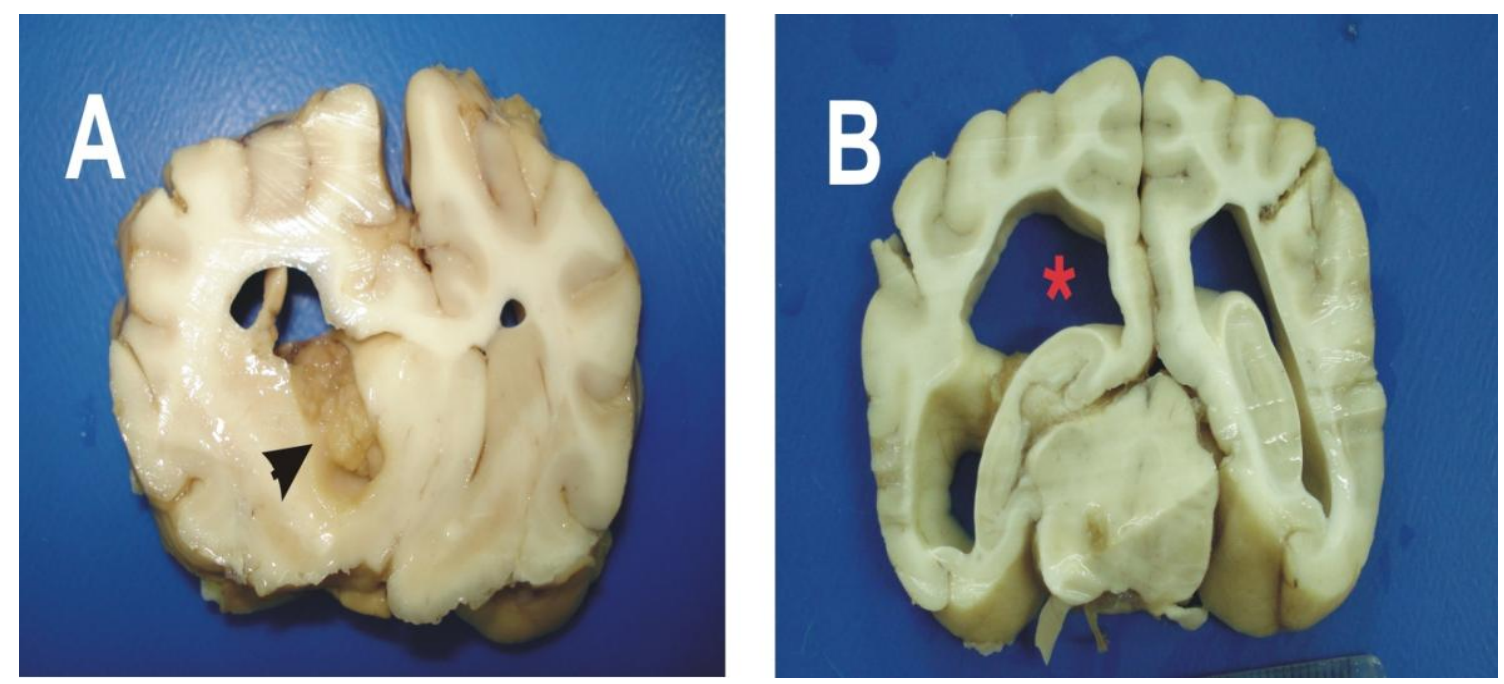

Figure 2. Dog. Photographs of the transversal slices of the affected dog's brain showing (A) a grayish mass on the floor of the right lateral ventricle (arrowhead), (B) associated with an important asymmetric ventricle dilatation $(*)$.
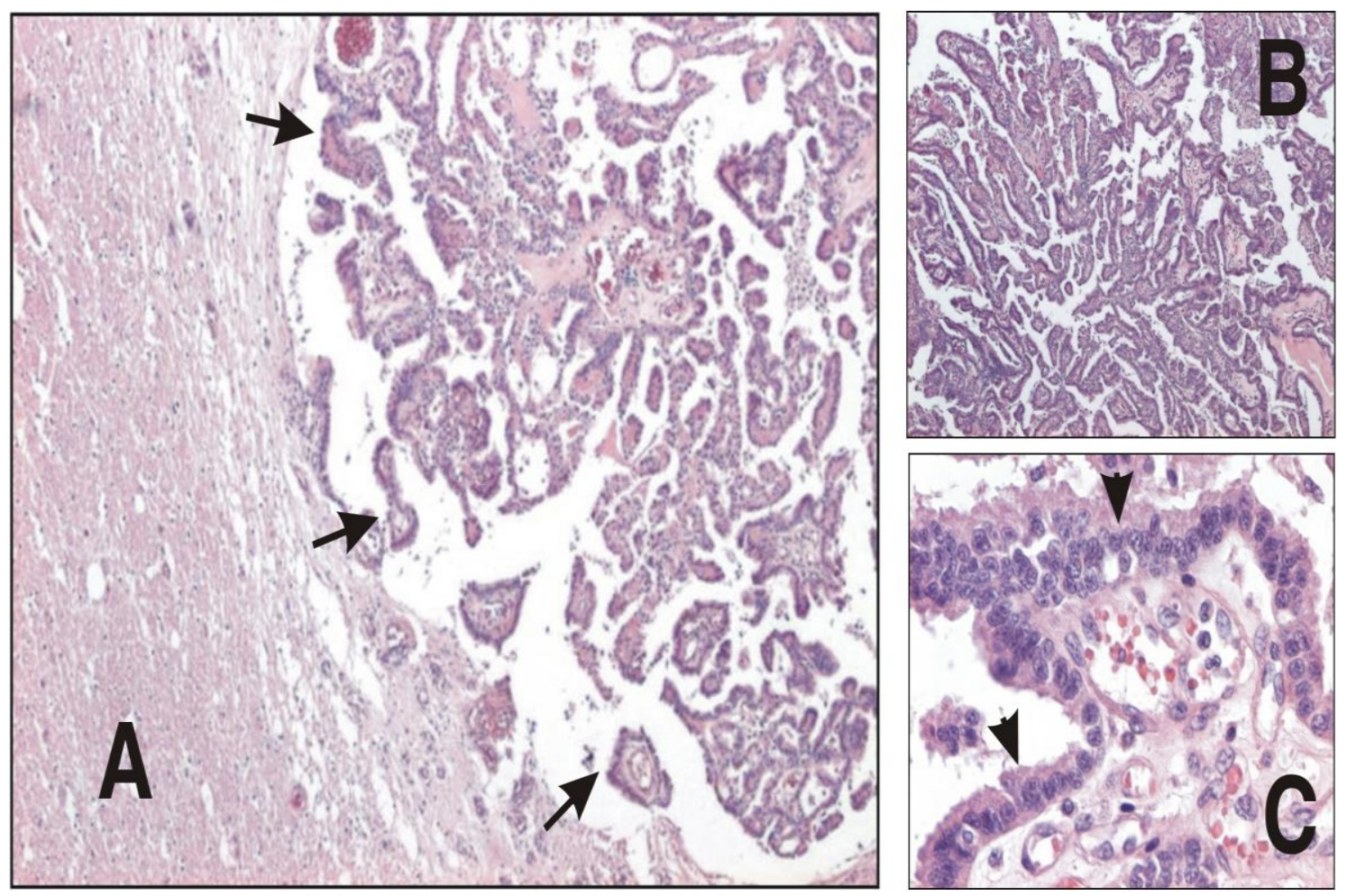

Figure 3. Dog. Histopathological analysis of brain ventricular tissue from the affected dog showing: (A) a multinodular, demarcated, partially encapsulated mass with moderate cellularity (arrows), and (B and C) Neoplastic cell form with fibrovascular papillary projections, which are lined by a single row of cuboidal to low columnar epithelium (arrowheads). HE. 
The necropsy of the dog from this report revealed asymmetric dilation of the lateral ventricles, with the presence of a soft grayish mass in the right lateral ventricle area. These gross pathologic findings are directly related to ventricular dilatation, where the choroid plexus mass may act as a mechanical barrier, preventing the physiological CSF drainage (Nashold et al., 1961). Another condition related with the ventricular dilation may be associated with an excessive secretion of the neoplastic choroid tissue, as described by Nashold et al. (1961) and Westworth et al. (2008). Obstructive hydrocephalus may be life threatening if the tumor causes CSF obstruction.

\section{REFERENCES}

FLETCHER, T.F. Spinal cord and meninges. In: EVANS, H.E.; MILLER, M.E. (Ed). Miller's Anatomy of the dog. 3th ed. Philadelphia: W.B. Saunders, 1993. p.800-828.

HAMMER, A.S.; COUTO, C.G.; GETZY, D.; HUNTER, W. Magnetic resonance imaging in a dog with a choroid plexus carcinoma. J. Small Anim. Pract., v.31, p.341-344, 1990.
KOESTNER, A.; HIGGINS, R.J. Tumors of the Nervous System. In: MEUTEN, D.J. (Ed). Tumors in Domestic Animals. 4.ed. Ames: Iowa State, 2002. p.697-738.

KURTZ, H.J.; HANLON, G.F. Choroid Plexus Papilloma in a Dog. Vet. Pathol., v.8, p.91-95, 1971.

MELO, E.L.A.; GARCIA, M.R.T.; FERNANDES, R.Y. et al. Lesões expansivas do plexo coroide. Radiol. Bras., v.36, p.379-384, 2003.

NASHOLD Jr., B.S.; MOORE Jr., G.T.; GILLS, J.P. Papilloma of the choroid plexus in a weimaraner dog. J. Neurosurg., v.18, p.250-251, 1961.

WESTWORTH, D.R.; DICKINSON, P.J.; VERNAU, W. et al. Choroid Plexus Tumors in 56 Dogs (1985-2007). J. Vet. Intern. Med., v.22, p.1157-1165, 2008 